\title{
The effect of betaine and rumen undegradable choline on growth rate and feed efficiency in calves
}

\author{
M. A. Gralak, Violetta Leśniewska, R. Puchala, W. Barej and \\ E. Dymnicki
}

\author{
Department of Animal Physiology, Faculty of Veterinary Medicine, \\ Warsaw Agricultural University \\ Nowoursynowska 166, 02-787 Warszawa, Poland
}

\begin{abstract}
The experiment was performed on 30 Black-and-White Lowland calves of $87.0-90.3 \mathrm{~kg}$ body weight. The animals were divided into threc groups fed meadow hay and a control granulated concentrate - C, supplemented with $2.5 \%$ betaine - B (Betafin - Finnsugar Bioproducts, Helsinki, Finland) or with $2.25 \%$ choline chloride - $\mathrm{CH}$ (Prince Agri Products, Inc., Quincy, Il, USA), which was equivalent to about $0.5 \%$ of the rumen undegradable cholinc.

The daily body gain of animals fed the C diet and the B diet was the same, $0.849 \pm 0.029 \mathrm{~kg}$, but in calves of the $\mathrm{CH}$ group was $0.898 \pm 0.029 \mathrm{~kg}$. The concentrate efficiency ratio was $3.06 \pm 0.097$, $3.13 \pm 0.097$ and $2.91 \pm 0.097 \mathrm{~kg}$ in the $\mathrm{C}, \mathrm{B}$ and $\mathrm{CH}$ group, respectively. The relative growth rate was higher $(\mathrm{P} \leq 0.10)$ in the $\mathrm{CH}$ group, reaching $131.7+1.40,169.1 \pm 2.71$ and $210.6+4.84 \%$ of the initial weight in the $5^{\text {th }}, 10^{\text {th }}$ and $15^{\text {th }}$ weeks, respectively. The results achieved suggest that $0.5 \%$ rumen undegradable choline has a positive effect on production performance of half year old calves. In contrast, $2.5 \%$ betaine supplementation had no effect on production performance even though it was administered at 5-times higher levels than the rumen undegradable choline.
\end{abstract}

KEY WORDS: calf, betaine, choline, growth rate

\section{INTRODUCTION}

Deficiency of the essential sulphur-containing amino acids, methionine and/or cysteine, often limit ruminant production (Armentano et al., 1997; Campbell ct al., 1997). Because betaine and choline are donors of free methyl groups their role in the organism is closely related to methionine and methylation processes (Barak et al., 1996). That is why they can positively influence the growth performance of 
monogastric animals. They are not usually considered as essential nutrients but they are important in many metabolic pathways (Mitchell et al., 1979; Burnham et al., 1996; Holler et al., 1996; Shronts, 1997). Thus the objective of this study was to estimate the effect of betaine and rumen undegradable choline on growth rate and feed efficiency ratio in calves.

\section{MATERIAL AND METHODS}

The experiment was performed on 30 Black-and-White Lowland calves of $87.0-90.3 \mathrm{~kg}$ body weight. The animals were divided into three groups fed meadow hay and a control granulated concentrate $-C$, supplemented with $2.5 \%$ betaine - B (Betafin - Finnsugar Bioproducts, Helsinki, Finland) or with $2.25 \%$ choline chloride - $\mathrm{CH}$ (Prince Agri Products, Inc., Quincy, Il, USA), which was calculated to be about $0.5 \%$ of the rumen undegradable choline. The betaine supplement was approximately 5 -times higher, because it was not protected against rumen degradation and we assumed $80 \%$ would be degraded in the rumen (unfortunately no rumen undegradable betaine was commercially available at the begining of 1997). A two week adaptation period, when the calves were fed the control concentrate and meadow hay ad libitum, was followed by 15 weeks of regular experiment when the animals were offered restricted amounts of concentrates (Table 1). Feed intake was controlled daily and body gain weekly.

Multiple analysis of variance (group x sex x period) for data analysis was carried out and the Scheffe test was applied for comparison of means at $\mathbf{P} \leq 0.05$ (Statgrafics software).

TABLE 1

The chemical composition of meadow hay and granulated concentrate

\begin{tabular}{lcccc}
\hline Item & $\begin{array}{c}\text { Meadow } \\
\text { hay }\end{array}$ & $\begin{array}{c}\text { Control } \\
\text { concentrate }\end{array}$ & $\begin{array}{c}\text { Betainc } \\
\text { concentrate }\end{array}$ & $\begin{array}{c}\text { Choline } \\
\text { concentrate }\end{array}$ \\
\hline Dry matter, \% & 84.1 & 92.3 & 92.6 & 92.5 \\
Organic matter, \% & 76.37 & 85.16 & 85.40 & 85.42 \\
Net energy, MJ/kg & 2.83 & 6.32 & 6.40 & 6.35 \\
Crude protein, \% & 11.3 & 17.0 & 17.2 & 17.2 \\
Crude fibre, \% & 31.15 & 4.66 & 4.50 & 4.51 \\
Ether extract, \% & 2.02 & 2.79 & 2.79 & 2.74 \\
Ash, \% & 7.73 & 7.14 & 7.20 & 7.08 \\
Ca, g/kg & 0.55 & 10.03 & 9.91 & 9.88 \\
P, g/kg & 0.27 & 9.84 & 9.90 & 9.86 \\
Betafin, \% & - & - & 2.50 & - \\
Choline chloride, \% & & - & - & 2.25 \\
\hline
\end{tabular}




\section{RESULTS AND DISCUSSION}

The initial and final body weights of the calves as well as the relative growth rates are presented in Table 2 . The differences in relative growth rate were confirmed statistically $(\mathrm{P} \leq 0.10)$ despite the short duration of the trial and the low animal numbers. The relative increase in body weight was higher in the animals fed the diet with rumen undegradable choline. The calves in this group achieved $131.7 \pm 1.40,169.1 \pm 2.71$ and $210.6 \pm 4.84 \%$ of their initial weight in 5 th, 10 th and 15 th weeks, respectively. The results observed suggest that $0.5 \%$ rumen unde-

TABLE 2

Initial weight, final weight and total gain of growing calves

\begin{tabular}{|c|c|c|c|c|c|c|}
\hline \multirow[t]{2}{*}{ Item } & \multirow[t]{2}{*}{$\mathrm{n}$} & \multirow{2}{*}{$\begin{array}{c}\text { Initial } \\
\text { weight, kg }\end{array}$} & \multirow{2}{*}{$\begin{array}{c}\text { Final weight } \\
\mathrm{kg}\end{array}$} & \multicolumn{3}{|c|}{ Relative growth rate, $\%$ of beginning weight } \\
\hline & & & & $5^{\text {th }}$ week & $10^{\text {th }}$ week & $15^{\text {th }}$ week \\
\hline \multicolumn{7}{|l|}{ Group } \\
\hline control & 10 & $90.3 \pm 5.61$ & $177.9 \pm 8.53$ & $128.6^{\mathrm{ab}} \pm 1.40$ & $161.9^{a} \pm 2.71$ & $197.0^{\mathrm{a}} \pm 4.84$ \\
\hline betaine & 10 & $90.3 \pm 5.61$ & $178.0 \pm 8.53$ & $127.5^{\mathrm{a}}+1.40$ & $163.2^{\mathrm{ab}}+2.71$ & $198.5^{\mathrm{a}} \pm 4.84$ \\
\hline choline & 10 & $87.0 \pm 5.61$ & $179.6 \pm 8.53$ & $131.7^{\mathrm{b}} \pm 1.40$ & $169.1^{b} \pm 2.71$ & $210.6^{\mathrm{b}} \pm 4.84$ \\
\hline \multicolumn{7}{|l|}{ Sex } \\
\hline male & 21 & $93.9 \pm 5.40$ & $187.1 \pm 5.40$ & $128.6 \pm 0.94$ & $163.3 \pm 1.82$ & $201.1 \pm 1.40$ \\
\hline female & 9 & $84.6 \pm 8.24$ & $169.9 \pm 8.24$ & $130.0 \pm 1.43$ & $166.2 \pm 2.77$ & $202.9 \pm 4.95$ \\
\hline Total & 30 & $89.2 \pm 4.93$ & $178.5 \pm 4.93$ & $129.3 \pm 0.86$ & $164.7 \pm 1.66$ & $202.0 \pm 2.96$ \\
\hline
\end{tabular}

means in columns with different superscripts, $(a, b)$ are significantly different $(\mathrm{P}<0.05)$

gradable choline has a positive effect on production performance of half year old calves. The daily body gain of animals fed the $\mathrm{C}$ and $\mathrm{B}$ diet was the same $-0.849 \pm 0.029 \mathrm{~kg}$, but was higher in calves of the $\mathrm{CH}$ group $-0.898 \pm 0.029 \mathrm{~kg}$ (Table 3). The concentrate efficiency ratio was $3.06 \pm 0.097,3.13 \pm 0.097$ and $2.91 \pm 0.097 \mathrm{~kg}$ in the $\mathrm{C}, \mathrm{B}$ and $\mathrm{CH}$ groups, respectively. The $2.5 \%$ betaine supplementation had no effect even though it was 5 -times higher than the addition of the rumen undegradable choline. Puchała et al. (1998) showed that duodenal infusion of betaine increased portal and jugular plasma concentration of methionine. Therefore the entire betaine was probably degraded in the rumen and none flowed into the duodenum. It was most probably metabolised to trimethylamine, methane and CO (Mitchell et al., 1979). There are reports that betaine improves the health and production performance of monogastric animals (Matthews et al., 1995, 1997; Emmert et al., 1996; Augustine et al., 1997). Hence it would be useful to examine the effect of rumen undegradable betaine in ruminants. We observed differences $(\mathrm{P} \leq 0.05)$ between the sexes in daily gain $(0.903 \pm 0.018$ - males and $0.827 \pm 0.028 \mathrm{~kg}-$ 
TABLE 3

Daily gain, concentrate and hay efficiency ratio in growing calves

\begin{tabular}{lcccc}
\hline Item & $\mathrm{n}$ & $\begin{array}{c}\text { Daily gain } \\
\mathrm{kg}\end{array}$ & $\begin{array}{c}\text { Concentrate } \\
\text { efficiency ratio } \\
\mathrm{kg} / \mathrm{kg} \text { feed }\end{array}$ & $\begin{array}{c}\text { Hay efficiency ratio } \\
\mathrm{kg} / \mathrm{kg} \text { feed }\end{array}$ \\
\hline $\begin{array}{l}\text { Group } \\
\quad \text { control }\end{array}$ & 30 & $0.849 \pm 0.029$ & $3.06 \pm 0.097$ & $1.24 \pm 0.068$ \\
$\quad \begin{array}{l}\text { betaine } \\
\text { choline }\end{array}$ & 30 & $0.849 \pm 0.029$ & $3.13 \pm 0.097$ & $1.35 \pm 0.068$ \\
$\begin{array}{l}\text { Sex } \\
\text { male }\end{array}$ & 30 & $0.898 \pm 0.029$ & $2.91 \pm 0.097$ & $1.23 \pm 0.068$ \\
$\quad$ female & 63 & $0.903 \pm 0.018^{\mathrm{a}}$ & $3.00 \pm 0.062$ & $1.20 \pm 0.043$ \\
Period & 27 & $0.827 \pm 0.028^{\mathrm{b}}$ & $3.07 \pm 0.094$ & $1.34 \pm 0.066$ \\
$\quad 1$ & & & & \\
2 & 30 & $0.781 \pm 0.029^{\mathrm{a}}$ & $2.74 \pm 0.097^{\mathrm{a}}$ & $0.78 \pm 0.068$ \\
$\quad 3$ & 30 & $0.886 \pm 0.029^{\mathrm{b}}$ & $2.94 \pm 0.097^{\mathrm{a}}$ & $1.28 \pm 0.068$ \\
Total & 30 & $0.929 \pm 0.029^{\mathrm{b}}$ & $3.42 \pm 0.097^{\mathrm{b}}$ & $1.75 \pm 0.068$ \\
\hline
\end{tabular}

means in columns with different superscripts $(a, b)$ are significantly different $(\mathrm{P}<0.05)$

females) and better feed efficiency during weeks 5-10 and weeks 10-15 of the experiment $(0.886 \pm 0.029$ and $0.929 \pm 0.029 \mathrm{~kg})$ than in the first period $(0.781 \pm 0.029 \mathrm{~kg})$.

\section{REFERENCES}

Armentano L.E., Bertics S.J., Ducharme G.A., 1997. Response of lactating cows to methionine or methionine plus lysine added to high protein diets based on alfalfa and heated soybeans. J. Dairy Sci. 80, 1194-1199

Augustine P.C., McNaughton J.L., Virtanen E., Rosh L., 1997. Effect of betaine on the growth performance of chicks inoculated with mixed cultures of avian Eimeria tenella and Eimeria acervulina in vitro and in vivo. Poultry Sci. 76, 802-809

Barak A.J., Beckenhauer H.C., Tuma D.J., 1996. Betaine, ethanol, and the liver: A review. Alcohol $13,395-398$

Burnham C.E., Buerck B., Schmidt C., Bucuvalas J.C., 1996. A liver-specific isoform of the betaine/ GABA transporter in the rat: cDNA sequence and organ distribution. Biochim. Biophys. Acta $1284,4-8$

Campbell C.G., Titgemeyer E.C., St-Jean G., 1997. Sulfur amino acid utilization by growing steers. J. Anim. Sci. 75, 230-238

Emmert J.L., Garrow T.A., Baker D.H., 1996. Hepatic betaine-homocysteine methyltransferase activity in the chicken is influenced by dietary intake of sulfur amino acids, choline and betaine. J. Nutr. 126, 2050-2058

Holler T., Cermak J.M., Blusztajn J.K., 1996. Dietary choline supplementation in pregnant rats increases hippocampal phospholipase D activity of the offspring. FASEB J. 10, 1653-1659 
Matthews J.O., Southern L.L., Pontif J.E., 1995. Effect of betaine (Betafin-BCR) on growth and carcass characteristics of finishing pigs. J. Anim. Sci. 73, Suppl. 1, 195

Matthews J.O., Ward T.L., Southern L.L., 1997. Interactive effects of betaine and monensin in uninfected and Eimeria acervulina-infected chicks. Poultry Sci. 76, 1014-1019

Mitchell A.D., Chappell A., Knox K.L., 1979. Metabolism of betaine in the ruminant. J. Anim. Sci. 49, 764-774

Puchała R., Zabielski R., Leśniewska V., Gralak M., Kiela P., Barej W., 1998. Effect of duodenal infusion of betaine or choline on amino acid concentration and duodenal electrical activity in Friesian calves. J. Agric Sci., Camb. (in press)

Shronts E.P., 1997. Essential nature of choline with implications for total parenteral nutrition. J. Amer. Diet. Assoc. 97, 639-646, 649 